\title{
W KIERUNKU RATYFIKACJI ZREWIDOWANEJ EUROPEJSKIEJ Karty Spolecznej - Polska WObec standardów ZEKS W ZAKRESIE OCHRONY TRWAŁOŚCI STOSUNKU PRACY
}

\section{Wstęp}

Przyjęta w 1996 r. Zrewidowana Europejska Karta Społeczna (ZEKS) to podstawowy dokument Rady Europy w dziedzinie społecznych praw człowieka, który stanowi element systemu międzynarodowej ochrony praw człowieka. Prawa uznane w ZEKS zaliczane są do podstawowych praw socjalnych ${ }^{1}$. Przyjęcie ZEKS stanowiło zwieńczenie procesu „rewitalizacji” Europejskiej Karty Społecznej (EKS) z 1961 r. ${ }^{2}$ Został on zapoczątkowany już w 1991 r. podczas Ministerialnej Konferencji Praw Człowieka zwołanej w Turynie, gdzie zdecydowano o potrzebie zaktualizowania i dostosowania merytorycznej zawartości Karty w celu uwzględnienia zasadniczych zmian społecznych i gospodarczych oraz zmian w ustawodawstwie europejskim i ustawodawstwach krajowych, jakie nastąpiły od czasu jej przyjęcia ${ }^{3}$. W za-

\footnotetext{
* Dr, Uniwersytet Rzeszowski; e-mail: aruszel@ur.edu.pl, https://orcid.org/00000003-4433-5884.

1 Parlament Europejski, Fundamental social rights in Europe, European Parliament, Directorate General for Research, Working Paper, Social Affairs series, SOCI 104 EN, Luxemburg, PE 1999, 168.629, https:/ / www.europarl.europa.eu/workingpapers/soci/pdf/ 104_en.pdf [dostęp: 12.08.2020 r.].

2 S. Evju, The European Social Charter - Instruments and procedures, Nordic Journal of Human Rights 2007, t. 25, nr 1, s. 59.

3 Zob. Preambuła, w: Zrewidowana Europejska Karta Społeczna, https://rm.coe. int/168047e175 [dostęp: 18.11.2020 r.] oraz pkt 7 Explanatory Report to the European Social Charter (revised), European Treaty Series No. 163, Strasbourg 3.05.1996, https:/ /rm.coe.
} 
mierzeniu jej twórców ZEKS ma stopniowo zastępować EKS, dlatego obok nowych ośmiu praw społecznych - uznanych w międzynarodowym systemie ochrony socjalnych praw człowieka - ZEKS przejmuje, częściowo w wersji zmienionej, dziewiętnaście praw gwarantowanych przez EKS oraz cztery przyjęte $\mathrm{w}$ protokole dodatkowym z $1988 \mathrm{r}{ }^{4}$

Polska podpisała Kartę 25 października 2005 r. Akt ten traktowano jako wyraz "przywiązania Polski do ideałów i zasad zapisanych w tym dokumencie" ${ }^{\prime 5}$. Jak dotąd Polska nie zdecydowała się na ratyfikację ZEKS, mimo że kwestia ta powraca co kilka lat. Powoływano się przy tym na względy natury fiskalnej, ekonomicznej i prawnej. Wskazywano, że poziom praw związanych z pracą i zabezpieczeniem społecznym w Polsce jest bliski spełnienia wymagań określonych w Karcie, dlatego należy podjąć wysiłki z jednej strony w kierunku zapewnienia lepszego przestrzegania praw już zagwarantowanych, z drugiej zaś polegające na wspieraniu warunków rozwoju gospodarczego oraz takim kształtowaniu systemu ochrony socjalnej, aby sprzyjał on efektywności podejmowanych działań, aktywizacji świadczeniobiorców i nie groził załamaniem równowagi finansowej ${ }^{6}$. Nacisk ze strony tzw. trzeciego sektora, w tym zwłaszcza przedstawicieli związków zawodowych, spowodował, że kwestia ratyfikacji ZEKS powróciła do dyskursu publicznego i stanowiła asumpt dla podjęcia niniejszych rozważań na temat poziomu zgodności krajowych regulacji prawa pracy ze standardami ochrony wynikającymi z Karty.

Jednym z nich są gwarancje wynikające z powszechnej ochrony trwałości stosunku pracy, które znalazły się wśród „nowych” praw społecznych zapisanych w ZEKS. Kwestia ochrony trwałości stosunku pracy stanowi jedno z kluczowych zagadnień w dyskusji, od dłuższego czasu

int/16800ccde4 [dostęp: 27.11.2020 r.]. R.R. Churchill, U. Khaliq, The Collective Complaints System of the European Social Charter: An Effective Mechanism for Ensuring Compliance with Economic and Social Rights?, Economic Journal of International Law 2004, t. 15, nr 3, s. 418.

4 Por. A.M. Świątkowski, w: Dorobek Rady Europy w zakresie kształtowania i ochrony praw społecznych. W kierunku powszechnej ratyfikacji Zrewidowanej Europejskiej Karty Społecznej, red. A.M. Świątkowski, Warszawa 2005.

5 Zob. https://www.mpips.gov.pl/aktualnosci-wszystkie/pomoc-spoleczna/art,4326, podpisanie-zrewidowanej-europejskiej-karty-spolecznej.html [dostęp: 26.09.2018 r.].

Poglądy na ratyfikację ZEKS ze strony nauki prawa pracy przedstawia J. Maciejewska, Kontrola wykonywania przez państwa międzynarodowych zobowiązan w sferze społecznych praw człowieka - doświadczenia Europejskiej Karty Społecznej, Studia z Zakresu Prawa Pracy i Polityki Społecznej 2006, t. 13, s. 181-182. 
toczącej się na temat przyszłości prawa pracy $^{7}$. Ze względu na zmiany, jakie pod wpływem globalizacji zachodzą w gospodarce światowej, coraz częściej pojawia się pytanie nie tylko o zakres, ale w ogóle o zasadność ingerencji państwa w swobodę świadczenia pracy ${ }^{8}$. ZEKS ujmuje prawo do ochrony trwałości stosunku pracy szerzej w porównaniu z art. 4 § 4 EKS, który prawo do rozsądnego okresu wypowiedzenia $\mathrm{w}$ razie zwolnienia z pracy ujmuje $\mathrm{w}$ kontekście realizacji prawa pracownika do sprawiedliwego wynagrodzenia $\mathrm{w}$ okresie przeznaczonym na poszukiwanie nowej pracy $^{9}$. Zgodnie z art. 24 ZEKS:

W celu zapewnienia skutecznego wykonywania prawa do ochrony w przypadku zwolnienia z pracy Strony zobowiązują się uznać:

a. prawo pracowników do ochrony przed zwolnieniem z pracy bez uzasadnionego powodu związanego $\mathrm{z}$ ich predyspozycjami lub zachowaniem, lub opartego na konieczności związanej z działalnością przedsiębiorstwa, zakładu lub służby;

b. prawo pracowników zwolnionych bez uzasadnionego powodu do odpowiedniego zadośćuczynienia lub do innego odpowiedniego wynagrodzenia szkody.

W tym celu Strony zobowiązują się zapewnić, by pracownik, który uważa, że został zwolniony bez uzasadnionego powodu, miał prawo odwołania się do bezstronnego organu.

Uzupełnieniem wskazanej regulacji są gwarancje wynikające z załącznika do ZEKS z dnia 30 maja 1996 r., który stanowi integralną część Karty (art. N, część III ZEKS). W znacznym stopniu regulacja ta bazuje na rozwiązaniach przyjętych w Konwencji Międzynarodowej Organizacji Pracy Nr 158 z 1982 r. dotyczącej rozwiązania stosunku pracy z inicjatywy pracodawcy ${ }^{10}$.

7 Zob. Globalization and the Future of Labour Law, red. J.D.R. Craig, S.M. Lynk, Cambridge 2011; I. Boruta, W sprawie przyszłości prawa pracy, Praca i Zabezpieczenie Społeczne 2005, nr 4, s. 3 i nn.; W. Muszalski, Przyszłość prawa pracy, Praca i Zabezpieczenie Społeczne, nr 7, s. 2 i nn.; B. Caruso, The Future of Labour Law: Traditional Models of Social Protection and a New Constitution of Social Rights, I Working Papers, Centro studi di Diritto del Lavoro Europeo „Massimo D' Antona”, 2002.

8 W. Walczak, Wptyw globalizacji i ogólnoświatowego kryzysu na podstawy $i$ warunki zatrudnienia. Wyzwania dla polskiego prawa pracy, w: Wspótczesne problemy prawa pracy i ubezpieczeń społecznych, red. L. Florek, Ł. Pisarczyk, Warszawa 2011, s. 80.

9 A.M. Świątkowski, The right to fair remuneration: European standards, Vilniaus universiteto leidykla mokslo darbai. Teisè 2011, nr 79, s. 186.

10 Pełny tekst Konwencji: http:/ / www.mop.pl/doc/html/konwencje/k158.html [dostęp: 10.10.2018 r.]. Nie została ratyfikowana przez Polskę. 
Postulat stworzenia warunków do skutecznej realizacji prawa do ochrony trwałości stosunku pracy został zapisany w części I ZEKS wśród celów polityki społecznej, do których w każdym przypadku powinny dążyć państwa członkowskie, to jest niezależnie od faktu związania się przepisem art. 24 ZEKS - zaliczonym do grupy przepisów tzw. non-core rights, z którego wynika gwarancja ochrony tego prawa ${ }^{11}$.

\section{Powszechny charakter ochrony trwałości stosunku pracy a podmiotowe zróżnicowanie zakresu ochrony}

Zasadniczo występujące na gruncie ZEKS prawo do ochrony w przypadku zwolnienia z pracy przysługuje wszystkim pracownikom. W załączniku do art. 24 ZEKS dopuszczono wyłączenie całkowicie lub częściowo spod ochrony tego przepisu niektórych kategorii pracowników, do których zaliczono: pracowników zatrudnionych na czas określony oraz na czas wykonania określonej pracy, pracowników zatrudnionych na okres próbny lub tych, którzy nie osiągnęli wymaganego stażu pracy, pod warunkiem, że okres próbny lub okres stażu będzie określony wcześniej i jego długość będzie rozsądna, jak również pracowników zatrudnionych dorywczo na krótki okres czasu.

Spośród wskazanych kategorii zatrudnienia Europejski Komitet Praw Społecznych (EKPS) kilkakrotnie zajmował stanowisko w przedmiocie dopuszczalności wyłączenia gwarancji ochronnych z art. 24 ZEKS w stosunku do osób zatrudnionych na okres próbny, biorąc pod uwagę kryterium długości okresu próbnego. W tym zakresie za rażąco nieuzasadnione EKPS uznał uchylenie ochrony w stosunku do pracowników zatrudnionych na okres próbny wynoszący 6 miesięcy ${ }^{12}$, a nawet na okres próbny obejmujący

11 Kryterium podziału praw społecznych na core rights (stanowiące tzw. twardy rdzeń normatywny Karty) i non-core rights, do których zalicza się prawo do ochrony trwałości stosunku pracy, nie stanowi znaczenia („ważności”) danego prawa, ale konieczność zachowania właściwej równowagi między różnymi grupami praw społecznych - zob. D. Gomien, D. Harris, L. Zwaak, Law and Practice of the European Convention on Human Rights and the European Social Charter, Strasbourg 1996, s. 380.

12 Konkluzje EKPS z 2012 r. w sprawie zgodności ustawodawstwa krajowego Bułgarii ze standardami ustanowionymi w ZEKS, https://hudoc.esc.coe.int/eng\#\{\%22ESCDcI dentifier\%22:[\%222012/def/BGR/24/EN\%22]\} [dostęp: 12.12.2018 r.]. 
26 miesięcy $^{13}$. Niezależnie od tego pojawia się pytanie o zgodność wyłączenia ochrony przed nieuzasadnionym zwolnieniem z pracy w odniesieniu do wskazanych kategorii pracowników z punktu widzenia zasady niedyskryminacji, która ma zastosowanie do wszystkich praw gwarantowanych przez ZEKS (art. E, część V ZEKS). Katalog przyczyn dyskryminacji podanych w tym przepisie jest otwarty, co oznacza, że zakaz dyskryminacji odnosi się także do innych niż w nim wskazane podstaw, w szczególności do rodzaju łączącej strony umowy o pracę, a także do takich okoliczności dotyczących pracownika, jak wiek, obowiązki rodzinne, niepełnosprawność, które często determinują wybór rodzaju zawieranej z pracownikiem umowy o pracę. Rodzaj zatrudnienia nie może uzasadniać wyłączenia lub ograniczenia zakresu ochrony trwałości stosunku pracy, chyba że jest to poparte obiektywną i uzasadnioną przyczyną. W odniesieniu do pracy na okres próbny oraz pracy dorywczej wyłączenie bądź ograniczenie zakresu ochrony uzasadnia cel i funkcja zatrudnienia na każdej z tych podstaw, które ze swej istoty kreują między stronami stosunek prawny o tymczasowym charakterze. Inaczej sytuacja przedstawia się $\mathrm{w}$ przypadku umowy o pracę na czas określony, której celem jest stworzenie między jej stronami trwałej, choć ograniczonej czasowo więzi prawnej ${ }^{14}$. W takim przypadku różnice w poziomie ochrony w stosunku do zatrudnienia na podstawie umowy o pracę na czas nieokreślony stanowią mniej korzystne traktowanie pracowników zatrudnionych na czas określony bez obiektywnego uzasadnienia opartego o cel i funkcję tej umowy, która w założeniu ma służyć stabilizacji zatrudnienia na czas w tej umowie określony celem wykonywania zadań oznaczonych w czasie ${ }^{15}$.

W zakresie powszechnej ochrony trwałości stosunku pracy polskie prawo pracy charakteryzuje znaczne zróżnicowanie zakresu ochrony przed nieuzasadnionym wypowiedzeniem stosunku pracy pracowników pozostających w terminowych stosunkach pracy (na podstawie umowy o pracę na okres próbny i na czas określony) oraz w bezterminowym stosunku pracy (na podstawie umowy o pracę na czas nieokreślony). Poziom ochrony pracowników terminowych, zwłaszcza zatrudnionych na czas określony,

13 Konkluzje EKPS z 2005 r. w sprawie zgodności ustawodawstwa krajowego Cypru ze standardami ustanowionymi w ZEKS, https://hudoc.esc.coe.int/eng\#\{\%22ESCDcIden tifier\%22:[\%222005/def/CYP/24/ /EN\%22]\} [dostęp: 12.12.2018 r.].

14 B. Wagner, Umowa o pracę na czas określony jako podstawa zatrudnienia terminowego, Przegląd Sądowy 2009, nr 11-12, s. 8.

15 Zob. wyrok SN z dnia 25 października 2007 r., II PK 49/07, OSNP 2008, nr 21-22, poz. 317. 
jest znacząco niższy w porównaniu z poziomem ochrony pracowników zatrudnionych na podstawie umowy o pracę na czas nieokreślony. W tym zakresie obowiązująca regulacja nie spełnia standardów wyznaczonych przez art. 24 ZEKS. Przepis art. 30 § 2 Kodeksu pracy (dalej: K.p.) dopuszcza możliwość w zasadzie nieograniczonego rozwiązania przez pracodawcę za wy powiedzeniem umowy o pracę na okres próbny bez względu na długość tego okresu. W świetle wskazanego wyżej stanowiska EKPS uchylenie ochrony należy w tym przypadku uznać za rażąco nieuzasadnione, nawet przy założeniu, że umowa o pracę na okres próbny tworzy między stronami więź o tymczasowym charakterze. $W$ przypadku umowy o pracę na czas określony wyłączenie ochrony przed nieuzasadnionym wypowiedzeniem umowy o pracę przez pracodawcę pozostaje w sprzeczności z zasadą niedyskryminacji pracowników zatrudnionych na czas określony w porównaniu z pracownikami zatrudnionymi na czas nieokreślony. Przyjęcie na gruncie art. $30 \S 4$ K.p. możliwości w zasadzie nieograniczonego wypowiadania umowy o pracę na czas określony, bez konieczności podawania przyczyny uzasadniającej, pozostawiło tę kategorię zatrudnionych praktycznie bez ochrony, prowadząc do licznych nadużyć w wykorzystywaniu umowy o pracę na czas określony jako podstawy zatrudnienia. Warto przy tym wskazać, że Trybunał Konstytucyjny w wyroku z dnia 2 grudnia 2008 r., ze zdaniem odrębnym T. Liszcz, usankcjonował ten stan rzeczy wskazując, że art. $30 \S 4$ K.p. w zakresie, w jakim pomija obowiązek wskazania przyczyny uzasadniającej w oświadczeniu pracodawcy o wypowiedzeniu umowy o pracę na czas określony, nie jest niezgodny z art. 2 oraz art. 32 Konstytucji $\mathrm{RP}^{16}$. Trybunał stanął na stanowisku, że wskazane zróżnicowanie w sposobie zakończenia stosunków pracy na podstawie umowy o pracę na czas określony i na czas nieokreślony uzasadnia społeczna funkcja tych umów i ich ekonomiczna treść, odwołując się przy tym do potrzeb w zakresie uelastycznienia rynku pracy. W zgłoszonym zdaniu odrębnym T. Liszcz słusznie zwróciła uwagę na to, że określenie szeroko prawa do rozwiązania umowy o pracę na czas określony przekreśla jej istotę, jaką jest gwarancja trwałości zatrudnienia pracownika w określonych ramach czasowych, a w konsekwencji prowadzi do nieuzasadnionego zróżnicowania sytuacji prawnej pracownika zatrudnionego na czas określony w porównaniu $\mathrm{z}$ pracownikiem zatrudnionym na podstawie umowy o pracę na czas nieokreślony. Występujące na gruncie polskiego porządku prawnego

16 Wyrok TK z dnia 2 grudnia 2008 r., P 48/07, OTK-A 2008, nr 10, poz. 173. 
zróżnicowanie zakresu ochrony przed nieuzasadnionym wypowiedzeniem stosunku pracy $\mathrm{w}$ odniesieniu do pracowników zatrudnionych na czas określony i nieokreślony z punktu widzenia zasady niedyskryminacji stało się przedmiotem orzeczenia Trybunału Sprawiedliwości Unii Europejskiej (TSUE) w sprawie C-38/13 ${ }^{17}$. W ten sposób TSUE pośrednio zakwestionował stanowisko polskiego Trybunału Konstytucyjnego wyrażone we wskazanym wyżej orzeczeniu.

\section{Gwarancja prawa do ochrony przez zwolnieniem $\mathrm{z}$ pracy bez „uzasadnionego" powodu}

Obowiązek wskazania przyczyny uzasadniającej rozwiązanie z pracownikiem umowy o pracę stanowi podstawowy środek ochrony stosunku pracy na gruncie polskiego prawa pracy ${ }^{18}$. Przepis art. $30 \S 4$ K.p. oparty na zastosowaniu klauzuli generalnej nie wskazuje, nawet przykładowo, okoliczności, które mogą stanowić „przyczynę uzasadniającą” rozwiązanie umowy o pracę. Ocena tych okoliczności następuje in concerto przez sąd w postepowaniu wszczętym w wyniku odwołania się pracownika od rozwiązania umowy o pracę $e^{19}$. Mimo że powołany przepis expressis verbis nie dokonuje rozróżnienia na przyczyny wypowiedzenia leżące po stronie pracownika i pracodawcy, podział taki już od dawna został ugruntowany w orzecznictwie Sądu Najwyższego, gdzie ponadto sprecyzowano wymagania, jakim powinna odpowiadać przyczyna uzasadniająca wypowiedzenie umowy o pracę oraz wskazano konkretne przyczyny mogące uzasadniać wypowiedzenie ${ }^{20}$. Zasadniczo za uzasadnione uznaje się wypowiedzenie umowy wynikające $\mathrm{z}$ obiektywnej potrzeby pracodawcy zwolnienia pracownika ${ }^{21}$.

17 Wyrok TSUE z dnia 13 marca 2014 r. w sprawie C-38/13, Małgorzata Nierodzik przeciwko Samodzielnemu Publicznemu Psychiatrycznemu Zakładowi Opieki Zdrowotnej im. dr. Stanisława Deresza w Choroszczy, ECLI:EU:C:2014:152.

18 A. Dral, Powszechna ochrona trwatości stosunku pracy. Tendencje zmian, Kraków 2009, s. 28.

19 L. Florek, w: Kodeks pracy. Komentarz, red. L. Florek, Warszawa 2011 [wyd. el. LEX].

20 Zob. uchwała SN z dnia 27 czerwca 1985 r., III PZP 10/85, OSNC 1985, nr 11, poz. 164 .

21 A. Dral, Powszechna ochrona..., 121 i nn. 
Przepis art. 30 § K.p. różnicuje obowiązek wskazania przyczyny uzasadniającej, a tym samym ochronę trwałości stosunku pracy, w zależności od rodzaju umowy o pracę oraz trybu, w jakim dochodzi do rozwiązania stosunku pracy. W zakresie rozwiązania za wypowiedzeniem umowy o pracę na czas określony i umowy o pracę na okres próbny pracodawca ma zasadniczo nieograniczoną swobodę zakończenia stosunku pracy opartą na cywilistycznej zasadzie swobody umów. Brak obowiązku podania przyczyny leżącej u podstaw rozwiązania za wypowiedzeniem terminowej umowy o pracę nie oznacza jednak, że w każdym przypadku przyczyna ta jest prawnie irrelewantna, a pracownik nie może $\mathrm{z}$ tego tytułu wywodzić żadnych roszczeń w stosunku do pracodawcy. Pogląd wyrażony przez $\mathrm{SN}$ w wyroku z dnia 5 grudnia $2007 \mathrm{r}{ }^{22}$ przesądza o dopuszczalności kwalifikacji wypowiedzenia terminowej umowy o pracę przez pracodawcę jako nadużycia prawa podmiotowego ze względu na jego sprzeczność z zasadami współżycia społecznego lub ze społeczno-gospodarczym przeznaczeniem prawa ${ }^{23}$ oraz oceny wypowiedzenia takiej umowy o pracę pod kątem naruszenia zasady równego traktowania i niedyskryminacji pracowników ${ }^{24}$. Powyższe otwiera możliwość badania przez sąd przyczyny wypowiedzenia terminowej umowy o pracę przez pracodawcę, jednak w znacznie ograniczonym zakresie wyznaczonym dyspozycją art. 8 K.p. oraz art. $18^{3 a} \S 1$ K.p.

Węższy zaś w stosunku do gwarancji wynikającej z art. 24 ZEKS jest standard ochrony przed rozwiązaniem umowy o pracę bez wypowiedzenia oparty na wskazaniu w ustawie konkretnych okoliczności - zawinionych i niezawinionych przez pracownika, które mogą uzasadniać rozwiązanie każdej umowy o pracę w tym trybie (art. 52 i art. 53 K.p.).

$\mathrm{Z}$ punktu widzenia gwarancji ochrony trwałości stosunku pracy na pozytywną ocenę zasługuje obowiązek pracodawcy przeprowadzenia procedury konsultacji związkowej zamiaru rozwiązania z pracownikiem umowy o pracę, wynikający z art. 38, art. 52 i art. 53 § 4 K.p. Ze względu na przedmiot konsultacji włączenie $\mathrm{w}$ procedurę rozwiązania umowy o pracę dodatkowego podmiotu - reprezentującej pracownika

22 Wyrok SN z dnia 5 grudnia 2007 r., II PK 122/07, LEX nr 499160. Sąd Najwyższy zauważył, że pracodawca wprawdzie nie musi wskazywać przyczyny wypowiedzenia umowy o pracę na czas określony, ale nie może swojego prawa nadużywać.

${ }^{23}$ Tak SN w wyrokach: z dnia 19 lipca 1984 r., I PRN 98/84, LEX nr 13555; z dnia 8 grudnia 2005 r., I PK 103/05, OSNP 2006, nr 21-22, poz. 321.

24 Zob. wyrok TK z dnia 2 grudnia 2008 r., P 48/07, Dz. U. z 2008 r. Nr 219, poz. 1409. 
zakładowej organizacji związkowej - podnosi poziom ochrony wynikający z art. 24 ZEKS.

W załączniku do art. 24 ZEKS wskazano przykładowy katalog powodów dotyczących pracownika, które nie mogą stanowić ważnej przyczyny rozwiązania stosunku pracy z inicjatywy pracodawcy. Do okoliczności tych zalicza się na przykład: członkostwo w organizacji związkowej, ubieganie się o jakikolwiek urząd związany z reprezentacją praw pracowniczych, wniesienie skargi oraz uczestnictwo w postępowaniu przeciwko pracodawcy opartym na naruszeniu przepisów prawa, rasa, kolor skóry, płeć, wiek, status materialny, obowiązki rodzinne, ciąża, wyznanie religijne, poglądy polityczne, pochodzenie narodowe i społeczne, urlop macierzyński i rodzicielski, a także czasowa niezdolność do pracy z powodu choroby. W świetle polskiego prawa pracy wskazane przyczyny także nie mogą stanowić przyczyny rozwiązania umowy o pracę bez wypowiedzenia, a niekiedy również bez wypowiedzenia przez to, że determinują objęcie pracownika szczególną ochroną przed rozwiązaniem umowy o pracę, stanowią kryteria niedozwolonej dyskryminacji w zakresie rozwiązania stosunku pracy bądź zostały uznane za nieuzasadnione powody rozwiązania umowy o pracę $\mathrm{w}$ ustawie lub $\mathrm{w}$ orzecznictwie sądowym. Podane przyczyny nie zostały ukształtowane jako bezwzględnie wyłączające możliwość rozwiązania stosunku pracy tak na gruncie ZEKS, jak i w świetle polskiego prawa pracy. Zdaniem EKPS zwolnienie pracownika $\mathrm{z}$ tych powodów jest dopuszczalne, jednak każdorazowo wymaga wyważenia między interesem pracownika i pracodawcy. Świadczy o tym stanowisko wyrażone przez EKPS w przedmiocie dopuszczalności uchylenia ochrony przed rozwiązaniem stosunku pracy po upływie określonego czasu nieobecności pracownika w pracy z powodu choroby. Uwzględniając interes ekonomiczny pracodawcy, wyrażający się w potrzebie właściwej organizacji pracy, Komitet uznał, że nieobecność pracownika w pracy, która zakłóca właściwe funkcjonowanie zakładu pracy i ze względu na czas jej trwania $\mathrm{w}$ istocie łączy się ze stałą potrzebą zastąpienia nieobecnego pracownika, może w konkretnym przypadku stanowić przyczynę uzasadniającą rozwiązanie stosunku pracy ${ }^{25}$. Dopuszczalność rozwiązania

25 Konkluzje EKPS z 2007 r. w sprawie zgodności ustawodawstwa krajowego Bułgarii ze standardami ustanowionymi w ZEKS, https://hudoc.esc.coe.int/eng\#\{\%22 ESCDcIdentifier\%22:[\%222007/def/BGR/24//EN\%22]\} [dostęp: 12.12 .2018 r.]; Konkluzje EKPS z 2005 r. w sprawie zgodności ustawodawstwa krajowego Norwegii ze 
umowy o pracę z pracownikiem nieobecnym $\mathrm{w}$ pracy została usankcjonowana $\mathrm{w}$ polskim prawie pracy $\mathrm{w}$ odniesieniu do przypadków uzasadniających rozwiązanie umowy o pracę bez wypowiedzenia (art. 53 § 1 pkt 1 i pkt 2 K.p.), dając pracodawcy możliwość zakończenia zatrudnienia w przypadkach długotrwałego nieświadczenia pracy przez pracownika ${ }^{26}$. Podobnie ustawa dopuszcza uchylenie szczególnej ochrony trwałości stosunku pracy niektórych kategorii pracowników w przypadku rozwiązania umowy o pracę bez wypowiedzenia z winy pracownika, a także w razie wyrażenia zgody przez zakładową organizację związkową na rozwiązanie umowy o pracę $\mathrm{z}$ takim pracownikiem.

Spośród wymienionych wyżej okoliczności najwięcej kontrowersji wywołuje kwestia dopuszczalności rozwiązania stosunku pracy z powodu osiągnięcia przez pracownika wieku emerytalnego. Zdaniem Komitetu, jeżeli z mocy prawa krajowego osiągnięcie przez pracownika wieku emerytalnego nie skutkuje wygaśnięciem stosunku pracy, pracodawca może jednostronnie rozwiązać stosunek pracy z takim pracownikiem, jeśli udowodni, że rozwiązanie stosunku pracy jest $w$ takim przypadku dodatkowo poparte przyczyną uzasadniającą $w$ rozumieniu art. 24 ZEKS ${ }^{27}$. Analogiczny pogląd wynika z ugruntowanego na tle tego zagadnienia orzecznictwa SN. Przykładowo w uchwale składu siedmiu sędziów SN z dnia 21 stycznia 2009 r. ${ }^{28}$ za niedopuszczalne uznano rozwiązanie umowy o pracę za wypowiedzeniem wyłącznie z powodu osiągnięcia przez pracownika wieku emerytalnego. Jako niezgodne z ZEKS Komitet uznaje uchylenie ochrony stosunku pracy w odniesieniu do pracowników, którzy osiągnęli wiek emerytalny, nawet jeżeli w świetle prawa krajowego pracodawca formalnie nie jest zobligowany do rozwiązania stosunku pracy z takim pracownikiem ${ }^{29}$. Zdaniem EKPS rozwiązanie stosunku pracy ze względu na osiągnięcie przez pracownika wieku emerytalnego będzie dopuszczalne w oparciu o przesłankę

standardami ustanowionymi w ZEKS, https:/ / hudoc.esc.coe.int/eng\#\{\%22ESCDcIdentifi er\%22:[\%222005/def/NOR/24//EN\%22]\} [dostęp: 12.12.2018 r.].

26 P. Prusinowski, w: System prawa pracy, t. 2. Indywidualne prawo pracy. Część ogólna, red. G. Goździewicz, Warszawa 2017, s. 630.

27 Decyzja EKPS z dnia 2 lipca 2013 r. w sprawie Fellesforbundet for Sjøfolk (FFFS) v. Norway, skarga nr 74/2011, https:// hudoc.esc.coe.int/eng\#\{\%22ESCDcIdentifier\%22: [\%22cc-74-2011-dmerits-en\%22]\} [dostęp: 12.12.2018 r.].

28 Uchwała SN z dnia 21 stycznia 2009 r., II PZP 13/08, OSNP 2009, nr 19-20, poz. 248.

29 Decyzja EKPS z dnia 2 lipca 2013 r. w sprawie Fellesforbundet for Sjøfolk (FFFS) v. Norway... 
„uzasadnionego powodu”, jeśli w świetle prawa krajowego jest ono obiektywnie i racjonalnie uzasadnione przez cel zgodny z prawem, w szczególności cel polityki zatrudnienia, rynku pracy, wymogi operacyjne przedsiębiorstw, zakładu lub służby, a środki mające służyć osiągnięciu tego celu są właściwe i konieczne ${ }^{30}$.

\section{Gwarancja prawa do „odpowiedniego” wynagrodzenia szkody}

Uprawnienie do „odpowiedniego" wynagrodzenia szkody, składające się na ochronę trwałości stosunku pracy na gruncie art. 24 ZEKS, realizuje funkcję kompensacyjną w stosunku do pracownika oraz funkcję prewencyjną i represyjną wobec pracodawcy. Zasadniczym celem omawianego świadczenia jest wyrównanie szkody poniesionej przez pracownika w związku z nieuzasadnionym zwolnieniem z pracy przez pracodawcę. Świadczenie to ma równocześnie napiętnować pracodawcę oraz powstrzymać go przed ewentualnymi dalszymi naruszeniami. Kwestią o podstawowym znaczeniu są warunki, jakim musi odpowiadać wynagrodzenie szkody, by kwalifikowało się jako „odpowiednie”. Jak wskazał EKPS, wynagrodzenie szkody spełnia ten warunek, jeżeli jest adekwatne do szkody poniesionej przez pracownika oraz należycie dolegliwe dla pracodawcy. Zasadniczo nie kwalifikuje się jako „odpowiednie” odszkodowanie z ustawowo określoną górną granicą (np. stanowiące równowartość wynagrodzenia miesięcznego lub jego wielokrotności ${ }^{31}$ ), chyba że poszkodowany - pracownik -jest równocześnieuprawniony dożądania świadczenia z tytułu szkody niemajątkowej (zadośćuczynienia) na innej podstawie

30 Konkluzje EKPS z 2008 r. w sprawie zgodności ustawodawstwa krajowego Litwy ze standardami ustanowionymi w ZEKS, https:/ / hudoc.esc.coe.int/eng\#\{\%22ESCDcIden tifier\%22:[\%222008/def/LTU/24/ /EN\%22]\} [dostęp: 12.12.2018 r.].

31 Konkluzje EKPS z 2003 r. w sprawie zgodności ustawodawstwa krajowego Bułgarii ze standardami ustanowionymi w ZEKS, https://hudoc.esc.coe.int/eng\#\{\%22ESCDcI dentifier\%22:[\%222003/def/BGR/24//EN\%22]\} [dostęp: 12.12.2018 r.]; Konkluzje EKPS z 2008 r. w sprawie zgodności ustawodawstwa krajowego Albanii ze standardami ustanowionymi w ZEKS, https:/ / hudoc.esc.coe.int/eng\#\{\%22ESCDcIdentifier\%22:[\%222008/ def/ALB/24/ /EN\%22]\} [dostęp: 12.12.2018 r.]. 
prawnej (np. na podstawie przepisów antydyskryminacyjnych) ${ }^{32}$, niezależnie od zagwarantowanej możliwości przywrócenia do pracy ${ }^{33}$. W takim przypadku, zdaniem EKPS, pracownikowi powinno przysługiwać także prawo do zwrotu wynagrodzenia utraconego $\mathrm{w}$ okresie między datą zwolnienia a przywróceniem do pracy ${ }^{34}$.

Funkcjonujący $\mathrm{w}$ polskim prawie pracy model roszczeń przysługujących pracownikowi z tytułu nieuzasadnionego rozwiązania stosunku pracy ma charakter mieszany. Opiera się on na połączeniu roszczeń restytucyjnych, mających na celu przywrócenie zatrudnienia, z roszczeniami majątkowymi, które polegają na możliwości przyznania pracownikowi odpowiedniej sumy pieniężnej ${ }^{35}$. Rodzaj i zakres roszczeń jest zróżnicowany i zależy z jednej strony od rodzaju umowy o pracę, z drugiej zaś od trybu, w jakim doszło do jej rozwiązania. Najszerszy zakres roszczeń przysługuje $\mathrm{w}$ przypadku nieuzasadnionego rozwiązania umowy o pracę na czas nieokreślony (za wypowiedzeniem i bez wypowiedzenia) oraz $\mathrm{w}$ określonym zakresie $\mathrm{w}$ razie nieuzasadnionego rozwiązania bez wypowiedzenia umowy o pracę na czas określony (art. 56 §1 K.p.). Tylko w tych przypadkach pracownikowi przysługuje roszczenie restytucyjne, które jednak może być zgłoszone alternatywnie do roszczenia o odszkodowanie $^{36}$ (art. $45 \S 1$ oraz art. $56 \S 1$ K.p.). W razie nieuzasadnionego wypowiedzenia terminowych umów o pracę oraz rozwiązania bez wypowiedzenia umowy o pracę na okres próbny i umowy o pracę na czas określony, $\mathrm{w}$ przypadku określonym $\mathrm{w}$ art. $59 \mathrm{~K} . \mathrm{p} \cdot{ }^{37}$, pracownikowi przysługuje wyłącznie prawo do odszkodowania. Wraz z przywróceniem zatrudnienia pracownik nabywa prawo do wynagrodzenia za czas pozostawania bez pracy, jednak zasadniczo w limitowanej ustawowo wysokości (art. 47

32 Konkluzje EKPS z 2012 r. w sprawie zgodności ustawodawstwa krajowego Rosji ze standardami ustanowionymi w ZEKS, https://hudoc.esc.coe.int/eng\#\{\%22ESCDcIdentifi er\%22:[\%222012/def/RUS/24/EN\%22]\} [dostęp: 12.12.2018 r.].

33 Konkluzje EKPS z 2012 r. w sprawie zgodności ustawodawstwa krajowego Finlandii ze standardami ustanowionymi w ZEKS, https://hudoc.esc.coe.int/eng\#\{\%22ESCDcI dentifier\%22:[\%222012/def/FIN/24/EN\%22]\} [dostęp: 12.12.2018 r.].

34 Konkluzje EKPS z 2012 r. w sprawie zgodności ustawodawstwa krajowego Rosji...; Konkluzje EKPS z 2003 r. w sprawie zgodności ustawodawstwa krajowego Bułgarii...

35 A. Dral, w: System prawa pracy, t. 2. Indywidualne prawo pracy..., s. 780.

36 Zob. wyrok SN z dnia 16 lipca 2015 r., II PK 169/14, LEX nr 1794312.

37 Jeżeli upłynął już termin, do którego umowa miała trwać, lub gdy przywrócenie do pracy byłoby niewskazane ze względu na krótki okres, jaki pozostał do upływu tego terminu. 
i art. 57 § 1 K.p.). Podaje to w wątpliwość wskazany przez EKPS cel tego świadczenia, które $\mathrm{w}$ założeniu ma rekompensować pracownikowi wynagrodzenie utracone w okresie pozostawania bez pracy. Wynagrodzenie za cały czas pozostawania bez pracy przysługuje wyłącznie niektórym kategoriom pracowników objętych szczególną ochroną trwałości stosunku pracy (art. 47 i art. 57 § 2 K.p.).

Odszkodowanie z tytułu wadliwego rozwiązania umowy o pracę ma w założeniu pełnić funkcję kompensacyjną, represyjną i prewencyjną, co jest mocno wątpliwe, biorąc pod uwagę sposób ukształtowania tego świadczenia. Zasadniczo funkcją odszkodowania jest kompensata uszczerbku w dobrach majątkowych poszkodowanego - pracownika, ustalonego zgodnie z zasadami wynikającymi z art. 361 § 2 Kodeksu cywilnego (dalej: K.c.) w zw. z art. 300 K.p. (odszkodowanie sensu stricto) ${ }^{38}$. W takim przypadku szkoda obejmuje wynagrodzenie utracone wskutek wadliwego rozwiązania umowy o pracę ${ }^{39}$. Powstanie roszczenia o odszkodowanie nie jest uzależnione od powstania szkody. W sytuacji gdy wadliwe rozwiązanie umowy o pracę nie doprowadziło do powstania szkody bądź szkoda jest niższa niż minimalna wskazana w ustawie kwota odszkodowania, pracownik nabywa prawo do odszkodowania, które wówczas pełni - w całości bądź w części - funkcję zadośćuczynienia pieniężnego za naruszenie prawa do pozostawania w stosunku pracy ${ }^{40}$. Przysługuje ono wtedy $\mathrm{z}$ samego faktu nieuzasadnionego rozwiązania stosunku pracy przez pracodawcę jako roszczenie o zapłatę z góry określonej, zryczałtowanej sumy pieniężnej. Oznacza to, że odszkodowanie może nie kompensować w pełni rozmiaru powstałej szkody. Wówczas odszkodowanie $z$ tytułu wadliwego rozwiązania stosunku pracy nie realizuje w pełni funkcji kompensacyjnej, także jego funkcja represyjna i prewencyjna jest mocno ograniczona. Na tle prawa do odszkodowania z tytułu niezgodnego z prawem rozwiązania umowy o pracę bez wypowiedzenia Trybunał Konstytucyjny w wyroku z dnia 27 listopada 2007 r. ${ }^{41}$ orzekł, że „art. 58 K.p. rozumiany w ten sposób, że wyłącza dochodzenie innych niż określone w art. 58 K.p., roszczeń odszkodowawczych, związanych

38 L. Florek, w: Kodeks pracy..., s. 348.

39 K. Jaśkowski, w: K. Jaśkowski, E. Maniewska, Komentarz aktualizowany do ustawy z dnia 26 czerwca 1974 r. Kodeks pracy (Dz.U.98.21.94), 2020 [wyd. el. LEX], komentarz do art. 471 K.p., teza 4.

40 L. Florek, w: Kodeks pracy..., s. 348.

41 Wyrok TK z dnia 27 listopada 2007 r., II SK 18/05, OTK-A 2007, nr 10, poz. 128. 
z bezprawnym rozwiązaniem umowy o pracę bez wypowiedzenia, jest niezgodny z art. 64 ust. $1 \mathrm{w}$ związku z art. 2 Konstytucji Rzeczypospolitej Polskiej oraz nie jest niezgodny z art. 45 ust. 1 i art. 77 ust. 2 Konstytucji”. Powyższe orzeczenie otworzyło drogę do dochodzenia dodatkowego odszkodowania na podstawie przepisów prawa cywilnego o odpowiedzialności deliktowej (art. 415 K.c.) lub odpowiedzialności kontraktowej (art. 471 i nast. K.c.) w zw. z art. 300 K.p. Ma ono jednak zastosowanie tylko w odniesieniu do art. 58 K.p. i nie przekłada się na sposób wykładni art. $47^{1}$ K.p. w odniesieniu do odszkodowania z tytułu wadliwego wypowiedzenia umowy o pracę ${ }^{42}$. Oznacza to, że w przypadku nieuzasadnionego wypowiedzenia umowy o pracę odszkodowanie zasądzone na rzecz pracownika w pełni wyczerpuje jego roszczenia $\mathrm{z}$ tego tytułu, zaś pracownik nie może dochodzić uzupełniająco roszczeń odszkodowawczych na podstawie przepisów K.c. Nie jest jednak wykluczone odszkodowanie na podstawie przepisów K.c. o ochronie dóbr osobistych, jeżeli w związku z wadliwym rozwiązaniem umowy o pracę dojdzie do naruszenia dobra osobistego pracownika przez pracodawcę ${ }^{43}$, oraz odszkodowanie $\mathrm{z}$ tytułu naruszenia zasady równego traktowania $\mathrm{w}$ zatrudnieniu z tytułu wadliwego - opartego na dyskryminującej podstawie - rozwiązania przez pracodawcę umowy o pracę. Jak wynika z wyroku SN z dnia 3 grudnia 2009 r. $^{44}$, prawo do roszczenia $\mathrm{z}$ tytułu wadliwego rozwiązania umowy o pracę jest niezależne od prawa do odszkodowania na podstawie art. $18^{3 \mathrm{~d}} \mathrm{~K}$.p. W doktrynie prawa pracy słusznie przyjmuje się, że w sytuacji uzyskania innego odszkodowania obok odszkodowania z art. $18^{3 \mathrm{~d}} \mathrm{~K}$.p. na poczet wyższego z nich należy zaliczyć niższe, traktując je jako korzyść odniesioną z tego samego zdarzenia, które wyrządziło szkodę ${ }^{45}$. W rezultacie odszkodowanie uzyskane przez pracownika z tytułu wadliwego rozwiązania umowy o pracę za wypowiedzeniem nie można uznać za "odpowiednie" w rozumieniu art. 24 ZEKS.

42 Tak SN w uchwale z dnia 18 czerwca 2009 r., I PZP 2/09, OSNP 2010, nr 1-2, poz. 1.

43 Zob. wyrok TK z dnia 22 maja 2013 r., P 46/11, OTK-A 2013, nr 4, poz. 42.

44 Wyrok SN z dnia 3 grudnia 2009 r., II PK 142/09, OSNP 2011, nr 11-12, poz. 153.

45 E. Maniewska, w: K. Jaśkowski, E. Maniewska, Komentarz..., komentarz do art. 183d K.p., teza 3.5.2; T. Liszcz, Odpowiedzialność odszkodowawcza pracodawcy wobec pracownika, Praca i Zabezpieczenie Społeczne 2009, nr 1, s. 3. 


\section{Gwarancja prawa odwołania do bezstronnego organu}

W świetle art. 24 ZEKS zasadnicze znaczenie dla skuteczności i efektywności uprawnień przysługujących pracownikowi z tytułu wadliwego rozwiązania umowy o pracę ma prawo odwołania się do bezstronnego organu od zwolnienia, które w ocenie pracownika jest nieuzasadnione. Bezstronny organ, którym może być sąd powszechny, komisja arbitrażowa czy arbiter, ma za zadanie zbadanie podstaw rozwiązania stosunku pracy post factum na wniosek pracownika. Prawo do kontroli decyzji pracodawcy musi być realne. W praktyce wpływ na skuteczność realizacji prawa odwołania się do bezstronnego organu mają: długość terminu na wniesienie odwołania przez pracownika, który powinien być rozsądny ${ }^{46}$, rozkład ciężaru dowodu istnienia ważnej przyczyny rozwiązania stosunku pracy oraz czas trwania postępowania przed organem rozpoznającym odwołanie pracownika. W ocenie EKPS postępowanie sądowe powinno zakończyć się w odpowiednim terminie ${ }^{47}$, zaś ciężar dowodu co do faktu, że zwolnienie pracownika było nieuzasadnione, powinien być równomiernie rozłożony między pracownika a pracodawcę ${ }^{48}$.

Polski system prawny rozstrzygania indywidualnych sporów ze stosunku pracy zasadniczo odpowiada standardom ustanowionym $\mathrm{w}$ art. 24 ZEKS. Prawo pracownika odwołania się do sądu pracy od decyzji pracodawcy o rozwiązaniu stosunku pracy jest uznawane za podstawowy instrument ochrony trwałości stosunku pracy w polskim prawie pracy ${ }^{49}$. W postępowaniu przed sądem pracy na pracodawcy spoczywa ciężar dowodu zasadności wypowiedzenia umowy o pracę. Wprawdzie nie wynika to wprost z przepisów K.p., ale zmianę w zakresie rozkładu ciężaru dowodu przewiduje

46 A. Dral, w: System prawa pracy, t. 2. Indywidualne prawo pracy..., s. 770.

47 Konkluzje EKPS z 2012 r. i 2016 r. w sprawie zgodności ustawodawstwa krajowego Rosji ze standardami ustanowionymi w ZEKS (z 2016 r.: https://hudoc.esc.coe.int/eng \#\{\%22ESCDcIdentifier\%22:[\%222016/def/RUS/24/EN\%22]\} [dostęp: 12.12.2018 r.]).

48 Konkluzje EKPS z 2008 r. w sprawie zgodności ustawodawstwa Armenii ze standardami ustanowionymi w ZEKS, https://hudoc.esc.coe.int/eng\#\{\%22ESCDcIde ntifier\%22:[\%222008/def/ARM/24//EN\%22]\} [dostęp: 12.12.2018 r.]; konkluzje EKPS z 2012 r. w sprawie zgodności ustawodawstwa krajowego Norwegii ze standardami ustanowionymi w ZEKS, https:/ / hudoc.esc.coe.int/eng\#\{\%22ESCDcIdentifier\%22:[\%222012/ def/NOR/24/EN\%22]\} [dostęp: 12.12.2018 r.].

49 A. Sobczyk, w: Prawo pracy, red. K.W. Baran, Kraków 2005, s. 247. 
orzecznictwo $\mathrm{SN}^{50}$. Ze względu na brak obowiązku pracodawcy podania przyczyny uzasadniającej wypowiedzenia terminowych umów o pracę sądowa kontrola ogranicza się $\mathrm{w}$ tym przypadku zasadniczo do kwestii formalnych, co zwłaszcza w odniesieniu do umowy o pracę na czas określony jest dużym mankamentem obowiązującej regulacji prawnej z punktu widzenia gwarancji prawa do oceny zasadności zwolnienia przez niezależny organ.

Aktualnie, po zmianie brzmienia art. 264 § 1 K.p., wprowadzonej ustawą nowelizacyjną z dnia 16 grudnia 2016 r. ${ }^{51}$, termin na wniesienie odwołania do sądu pracy jest jednolity i wynosi 21 dni niezależnie od trybu rozwiązania umowy o pracę. Poprzednio dla wypowiedzenia umowy o pracę termin na wniesienie odwołania wynosił $7 \mathrm{dni}$. W świetle poglądu wyrażonego przez A. Rycak na gruncie poprzedniego stanu prawnego, przysługujący pracownikowi siedmiodniowy termin na wniesienie odwołania od wypowiedzenia umowy o pracę nie stanowił realnej gwarancji realizacji prawa do odwołania się do bezstronnego organu ${ }^{52}$. Z drugiej strony w doktrynie wskazywano, że krótki termin na wniesienie odwołania ma na celu stabilizację obrotu prawnego ${ }^{53}$, usunięcie stanu niepewności odnośnie do ostatecznego wyniku kwestii rozwiązania stosunku pracy, co nie pozostaje bez znaczenia także dla działalności pracodawcy w warunkach gospodarki wolnorynkowej. Z punktu widzenia gwarancji z art. 24 ZEKS wydłużenie terminu na wniesienie odwołania do sądu pracy należy uznać za pożądane w kontekście przysługującego pracownikowi prawa do oceny zasadności wypowiedzenia umowy o pracę przez bezstronny organ oraz możliwości przygotowania się do obrony swoich praw w takim postępowaniu. Niezależnie od tego na aprobatę zasługuje ujednolicenie terminów do wniesienia odwołania do sądu pracy, wskazanych w art. 264 K.p., gdyż poprzednio obowiązujące zróżnicowanie oparte na podstawie zwolnienia pracownika było nieuzasadnione.

Na gruncie obecnie obowiązujących przepisów K.p. brak jest regulacji, która expressis verbis nakładałaby na sąd pracy obowiązek dążenia do szybkiego rozstrzygnięcia sprawy ${ }^{54}$. W postępowaniu w sprawach z zakresu

50 Zob. wyrok SN z dnia 8 marca 1977 r., I PRN 7/77, OSNC 1977, nr 9, poz. 172.

51 Ustawa z dnia 16 grudnia 2016 r. o zmianie niektórych ustaw w celu poprawy otoczenia prawnego przedsiębiorców, Dz. U. z 2016 r. poz. 2255 z późn. zm.

52 A. Rycak, Powszechna ochrona trwałości stosunku pracy, Warszawa 2013.

53 Tak J. Stelina, w: Kodeks pracy z komentarzem, red. U. Jackowiak, Warszawa 2012 [wyd. el. LEX].

54 Obowiązek taki ustanawiał art. $246 \S 1$ K.p. 
prawa pracy obowiązuje ogólna dyrektywa wynikająca z art. 6 Kodeksu postępowania cywilnego (dalej: K.p.c.), zgodnie z którą sąd powinien przeciwdziałać przewlekaniu postępowania i dążyć do tego, aby rozstrzygnięcie nastąpiło na pierwszym posiedzeniu, jeżeli jest to możliwe bez szkody dla wyjaśnienia sprawy. Zasada szybkości postępowania w sprawach z zakresu prawa pracy jest uznawana za aspekt funkcji ochronnej procesowego prawa pracy $^{55}$. Zasadę szybkości postępowania realizują obowiązujące przepisy procedury cywilnej, które przewidują: wstępne badanie sprawy na posiedzeniu przygotowawczym, mające na celu wyjaśnienie okoliczności istotnych dla szybkiego rozpoznania sprawy (art. $467 \S 3^{2}$ K.p.c.); obowiązek wyznaczenia terminu posiedzenia, na którym sprawa ma zostać rozpoznania, $\mathrm{w}$ taki sposób, żeby od daty zakończenia posiedzenia przygotowawczego nie upłynął więcej niż miesiąc, a jeżeli go nie przeprowadzono, więcej niż sześć miesięcy od dnia złożenia odpowiedzi na pozew lub upływu terminu do jej złożenia (art. 471 K.p.c.); możliwość wzywania i zawiadamiania przez sąd stron, świadków i biegłych, dokonywania doręczeń i zarządzeń mających na celu przygotowanie rozprawy w sposób, który uzna za najbardziej celowy, nawet $\mathrm{z}$ pominięciem sposobów przewidzianych przez przepisy ogólne, jeżeli uzna to za niezbędne do przyśpieszenia rozpoznania sprawy (art. 472 K.p.c.). Regulacja art. $477^{2} \S 2$ K.p.c. częściowo przeciwdziała negatywnym skutkom, jakie w stosunku do pracownika mogą wynikać z przedłużającego się postepowania sądowego wywołanego odwołaniem od rozwiązania umowy o pracę. $Z$ tych względów zasługuje na aprobatę w kontekście gwarancji $\mathrm{z}$ art. 24 ZEKS. Przepis ten przewiduje możliwość zobowiązania pracodawcy do dalszego zatrudniania pracownika do czasu prawomocnego zakończenia postępowania $\mathrm{w}$ razie uwzględnienia roszczenia pracownika o uznanie wypowiedzenia za bezskuteczne albo o przywrócenie do pracy. Ze względu na faktyczną długość postępowań sądowych w sprawach pracowniczych, których czas trwania wielokrotnie wykracza poza okres wypowiedzenia umowy o pracę, za w pełni uzasadnioną należy uznać możliwość zastosowania wskazanej instytucji w przypadku przywrócenia pracownika do pracy. Możliwość taka została wprowadzona w wyniku nowelizacji procedury cywilnej, która weszła w życie w dniu 7 listopada 2019 r. ${ }^{56}$

55 M. Skąpski, w: System prawa pracy, t. 4. Procesowe prawo pracy, red. K.W. Baran, Warszawa 2016, s. 51.

56 Ustawa z dnia 4 lipca 2019 r. o zmianie ustawy - Kodeks postępowania cywilnego oraz niektórych innych ustaw, tekst jednolity: Dz. U. z 2020 r. poz. 1086. 


\section{Zakończenie}

Z przeprowadzonych rozważań wynika, że obowiązujące na gruncie polskiego porządku prawnego regulacje $\mathrm{z}$ zakresu prawnej ochrony trwałości stosunku pracy tylko częściowo odpowiadają standardom ochrony ustanowionym w art. 24 ZEKS. Polskie rozwiązania z zakresu ochrony trwałości stosunku pracy nie gwarantują pracownikom skutecznej i efektywnej ochrony przed arbitralnym rozwiązaniem umowy o pracę przez pracodawcę. Powyższe dotyczy powszechnej ochrony trwałości stosunku pracy oraz ochrony szczególnej niektórych kategorii pracowników przed nieuzasadnionym rozwiązaniem terminowych umów o pracę, zwłaszcza umowy o pracę na czas określony. Z tego powodu decyzja o ratyfikacji ZEKS przez Polskę powinna zostać poprzedzona dostosowaniem regulacji polskiego prawa pracy do standardów ochronnych wynikających z art. 24 ZEKS.

Zasadniczym mankamentem polskich rozwiązań prawnych jest znaczne zróżnicowanie zakresu ochrony przed nieuzasadnionym rozwiązaniem umowy o pracę przez pracodawcę ze względu na rodzaj łączącej strony umowy o pracę oraz tryb jej rozwiązania. Różnice w poziomie ochrony między pracownikami zatrudnionymi na czas określony i nieokreślony nie znajdują uzasadnienia w świetle zasady niedyskryminacji pracowników. Po pierwsze, za niezgodne z art. 24 ZEKS należy uznać pozbawienie pracowników zatrudnionych na czas określony gwarancji prawa do ochrony przed nieuzasadnionym wypowiedzeniem umowy o pracę przez zwolnienie pracodawcy z obowiązku wskazania pracownikowi przyczyny uzasadniającej rozwiązanie umowy o pracę w tym trybie. Po drugie, niezgodny $z$ art. 24 ZEKS jest ograniczony zakres roszczeń przysługujących pracownikowi w przypadku nieuzasadnionego rozwiązania umowy o pracę na czas określony oraz w każdym przypadku rozwiązania umowy o pracę - ustawowo określona górna granica odszkodowania i wynagrodzenia za czas pozostawania bez pracy. $W$ rezultacie $w$ tych przypadkach wynagrodzenie szkody nie jest proporcjonalne do szkody poniesionej przez pracownika ani odpowiednio dolegliwe dla pracodawcy, tym samym nie jest „odpowiednie" w rozumieniu art. 24 ZEKS. Dotyczy to zwłaszcza rozwiązania umowy o pracę na czas określony, gdzie brak roszczenia restytucyjnego nie został w odpowiedni sposób zrekompensowany roszczeniem o odszkodowanie, które jest nieproporcjonalnie niskie do straty, jaką stanowi dla pracownika utrata zatrudnienia przed umówionym terminem. Ograniczona zasadniczo do kwestii formalnych sądowa kontrola rozwiązania za wypowiedzeniem 
umowy o pracę na czas określony sprawia, że pracownik faktycznie jest pozbawiony gwarancji prawa do kontroli zasadności wypowiedzenia umowy o pracę przez sąd pracy, wynikającej z art. 24 ZEKS.

\section{Bibliografia}

\section{Źródła}

\section{Akty prawne}

Konwencja Nr 158 Międzynarodowej Organizacji Pracy dotycząca rozwiązania stosunku pracy z inicjatywy pracodawcy, 23.11.1985, http:/ / www.mop.pl/doc/ $\mathrm{html} /$ konwencje/k158.html [dostęp: 10.10.2018 r.].

Ustawa z dnia 16 grudnia 2016 r. o zmianie niektórych ustaw w celu poprawy otoczenia prawnego przedsiębiorców, Dz. U. z 2016 r. poz. 2255 z późn. zm.

Ustawa z dnia 4 lipca 2019 r. o zmianie ustawy - Kodeks postępowania cywilnego oraz niektórych innych ustaw, tekst jednolity: Dz. U. z 2020 r. poz. 1086.

\section{Dokumenty}

Explanatory Report to the European Social Charter (revised), European Treaty Series No. 163, Strasbourg 3.05.1996, https://rm.coe.int/16800ccde4 [dostęp: 27.11.2020 r.].

Konkluzje EKPS z 2003 r. w sprawie zgodności ustawodawstwa krajowego Bułgarii ze standardami ustanowionymi w ZEKS, https:/ / hudoc.esc.coe.int/eng\#\{\%22 ESCDcIdentifier\%22:[\%222003/def/BGR/24//EN\%22]\} [dostęp: 12.12.2018 r.].

Konkluzje EKPS z 2005 r. w sprawie zgodności ustawodawstwa krajowego Cypru ze standardami ustanowionymi w ZEKS, https:/ / hudoc.esc.coe.int/eng\#\{\%22 ESCDcIdentifier\%22:[\%222005/def/CYP/24//EN\%22]\} [dostęp: 12.12.2018 r.].

Konkluzje EKPS z 2005 r. w sprawie zgodności ustawodawstwa krajowego Norwegii ze standardami ustanowionymi w ZEKS, https:/ / hudoc.esc.coe.int/eng\#\{\%22E SCDcIdentifier\%22:[\%222005/def/NOR/24//EN\%22]\} [dostęp: 12.12.2018 r.].

Konkluzje EKPS z 2007 r. w sprawie zgodności ustawodawstwa krajowego Bułgarii ze standardami ustanowionymi w ZEKS, https:/ / hudoc.esc.coe.int/eng\#\{\%22 ESCDcIdentifier\%22:[\%222007/def/BGR/24//EN\%22]\} [dostęp: 12.12.2018 r.].

Konkluzje EKPS z 2008 r. w sprawie zgodności ustawodawstwa krajowego Albanii ze standardami ustanowionymi w ZEKS, https:/ / hudoc.esc.coe.int/eng\# $\{\% 22$ ESCDcIdentifier\%22:[\%222008/def/ALB/24//EN\%22]\} [dostęp: 12.12 .2018 r.].

Konkluzje EKPS z 2008 r. w sprawie zgodności ustawodawstwa Armenii ze standardami ustanowionymi w ZEKS, https://hudoc.esc.coe.int/eng\#\{\%22ESCD cIdentifier\%22:[\%222008/def/ARM/24//EN\%22]\} [dostęp: 12.12.2018 r.]. 
Konkluzje EKPS z 2008 r. w sprawie zgodności ustawodawstwa krajowego Litwy ze standardami ustanowionymi w ZEKS, https:/ / hudoc.esc.coe.int/eng\# $\{\% 22$ ESCDcIdentifier\%22:[\%222008/def/LTU/24//EN\%22]\} [dostęp: 12.12.2018 r.].

Konkluzje EKPS z 2012 r. w sprawie zgodności ustawodawstwa krajowego Bułgarii ze standardami ustanowionymi w ZEKS, https:/ / hudoc.esc.coe.int/eng\#\{\%22ESC DcIdentifier\%22:[\%222012/def/BGR/24/EN\%22]\} [dostęp: 12.12.2018 r.].

Konkluzje EKPS z 2012 r. w sprawie zgodności ustawodawstwa krajowego Finlandii ze standardami ustanowionymi w ZEKS, https:/ / hudoc.esc.coe.int/eng\#\{\%2 2ESCDcIdentifier\%22:[\%222012/def/FIN/24/EN\%22]\} [dostęp: 12.12.2018 r.].

Konkluzje EKPS z 2012 r. w sprawie zgodności ustawodawstwa krajowego Norwegii ze standardami ustanowionymi w ZEKS, https:/ / hudoc.esc.coe.int/eng\#\{\%22 ESCDcIdentifier\%22:[\%222012/def/NOR/24/EN\% 22]\} [dostęp: 12.12 .2018 r.].

Konkluzje EKPS z 2012 r. w sprawie zgodności ustawodawstwa krajowego Rosji ze standardami ustanowionymi w ZEKS, https:/ / hudoc.esc.coe.int/eng\#\{\%2 2ESCDcIdentifier\%22:[\%222012/def/RUS/24/EN\%22]\} [dostęp: 12.12.2018 r.].

Konkluzje EKPS z 2016 r. w sprawie zgodności ustawodawstwa krajowego Rosji ze standardami ustanowionymi w ZEKS, https://hudoc.esc.coe.int/eng\#\{\%2 2ESCDcIdentifier\%22:[\%222016/def/RUS/24/EN\%22]\} [dostęp: 12.12.2018 r.].

Parlament Europejski, Fundamental social rights in Europe, European Parliament, Directorate General for Research, Working Paper, Social Affairs series, SOCI 104 EN, Luxemburg, PE 1999, 168.629, https:/ / www.europarl.europa.eu/workingpapers/soci/pdf/104_en.pdf [dostęp: 12.08.2020 r.].

Zrewidowana Europejska Karta Społeczna, https://rm.coe.int/168047e175 [dostęp: 18.11.2020 r.].

\section{Orzecznictwo}

Decyzja EKPS z dnia 2 lipca 2013 r. w sprawie Fellesforbundet for Sjøfolk (FFFS) v. Norway, skarga nr 74/2011, https:/ / hudoc.esc.coe.int/eng\#\{\%22ESCDcId entifier\%22:[\%22cc-74-2011-dmerits-en\%22]\} [dostęp: 12.12.2018 r.].

Uchwała SN z dnia 27 czerwca 1985 r., III PZP 10/85, OSNC 1985, nr 11, poz. 164. Uchwała SN z dnia 21 stycznia 2009 r., II PZP 13/08, OSNP 2009, nr 19-20, poz. 248. Uchwała SN z dnia 18 czerwca 2009 r., I PZP 2/09, OSNP 2010, nr 1-2, poz. 1. Wyrok SN z dnia 8 marca 1977 r., I PRN 7/77, OSNC 1977, nr 9, poz. 172. Wyrok SN z dnia 19 lipca 1984 r., I PRN 98/84, LEX nr 13555.

Wyrok SN z dnia 8 grudnia 2005 r., I PK 103/05, OSNP 2006, nr 21-22, poz. 321. Wyrok SN z dnia 25 października 2007 r., II PK 49/07, OSNP 2008, nr 21-22, poz. 317. Wyrok SN z dnia 5 grudnia 2007 r., II PK 122/07, LEX nr 499160.

Wyrok SN z dnia 3 grudnia 2009 r., II PK 142/09, OSNP 2011, nr 11-12, poz. 153. Wyrok SN z dnia 19 marca 2014 r., I PK 187/13, OSNP 2015, nr 9, poz. 120.

Wyrok SN z dnia 17 czerwca 2014 r., II PK 247/13, LEX nr 1496284.

Wyrok SN z dnia 16 lipca 2015 r., II PK 169/14, LEX nr 1794312. 
Wyrok TK z dnia 27 listopada 2007 r., II SK 18/05, OTK-A 2007, nr 10, poz. 128. Wyrok TK z dnia 2 grudnia 2008 r., P 48/07, Dz. U. z 2008 r. Nr 219, poz. 1409. Wyrok TK z dnia 2 grudnia 2008 r., P 48/07, OTK-A 2008, nr 10, poz. 173. Wyrok TK z dnia 22 maja 2013 r., P 46/11, OTK-A 2013, nr 4, poz. 42.

Wyrok TSUE z dnia 13 marca 2014 r. w sprawie C-38/13, Małgorzata Nierodzik przeciwko Samodzielnemu Publicznemu Psychiatrycznemu Zakładowi Opieki Zdrowotnej im. dr. Stanisława Deresza w Choroszczy, ECLI:EU:C:2014:152.

\section{Literatura i netografia}

Boruta I., W sprawie przyszłości prawa pracy, Praca i Zabezpieczenie Społeczne 2005, nr 4.

Caruso B., The Future of Labour Law: Traditional Models of Social Protection and a New Constitution of Social Rights, I Working Papers, Centro studi di Diritto del Lavoro Europeo „Massimo D’Antona”, 2002.

Churchill R.R., Khaliq U., The Collective Complaints System of the European Social Charter: An Effective Mechanism for Ensuring Compliance with Economic and Social Rights?, Economic Journal of International Law 2004, t. 15, nr 3.

Dorobek Rady Europy w zakresie ksztattowania i ochrony praw społecznych. W kierunku powszechnej ratyfikacji Zrewidowanej Europejskiej Karty Społecznej, red. A.M. Świątkowski, Warszawa 2005.

Dral A., Powszechna ochrona trwałości stosunku pracy. Tendencje zmian, Kraków 2009.

Evju S., The European Social Charter - Instruments and procedures, Nordic Journal of Human Rights 2007, t. 25, nr 1.

Globalization and the Future of Labour Law, red. J.D.R. Craig, S.M. Lynk, Cambridge 2011.

Gomien D., Harris D., Zwaak L., Law and Practice of the European Convention on Human Rights and the European Social Charter, Strasbourg 1996.

https://www.mpips.gov.pl/aktualnosci-wszystkie/pomoc-spoleczna/art,4326, podpisanie-zrewidowanej-europejskiej-karty-spolecznej.html [dostęp: 26.09.2018 r.]. Jaśkowski K., Maniewska E., Komentarz aktualizowany do ustawy z dnia 26 czerwca 1974 r. Kodeks pracy (Dz.U.98.21.94), 2020 [wyd. el. LEX].

Kodeks pracy. Komentarz, red. L. Florek, Warszawa 2011 [wyd. el. LEX].

Kodeks pracy z komentarzem, red. U. Jackowiak, Warszawa 2012 [wyd. el. LEX].

Liszcz T., Odpowiedzialność odszkodowawcza pracodawcy wobec pracownika, Praca

i Zabezpieczenie Społeczne 2009, nr 1.

Liszcz T., Prawo pracy, Warszawa 2016.

Maciejewska J., Kontrola wykonywania przez państwa międzynarodowych zobowiazań w sferze społecznych praw człowieka - doświadczenia Europejskiej Karty Społecznej,

Studia z Zakresu Prawa Pracy i Polityki Społecznej 2006, t. 13.

Muszalski W., Przyszłość prawa pracy, Praca i Zabezpieczenie Społeczne, nr 7.

Prawo pracy, red. K.W. Baran, Kraków 2005.

Rycak A., Powszechna ochrona trwałości stosunku pracy, Warszawa 2013. 
System prawa pracy, t. 2. Indywidualne prawo pracy. Część ogólna, red. G. Goździewicz, Warszawa 2017.

System prawa pracy, t. 4. Procesowe prawo pracy, red. K.W. Baran, Warszawa 2016.

Świątkowski A.M., The right to fair remuneration: European standards, Vilniaus universiteto leidykla mokslo darbai. Teisè 2011, nr 79.

Wagner B., Umowa o prace na czas określony jako podstawa zatrudnienia terminowego, Przegląd Sądowy 2009, nr 11-12.

Współczesne problemy prawa pracy i ubezpieczeń społecznych, red. L. Florek, Ł. Pisarczyk, Warszawa 2011.

Zarys systemu prawa pracy, t. 1. Część ogólna prawa pracy, red. K.W. Baran, Warszawa 2010.

\section{Streszczenie}

Niniejszy artykuł koncentruje się na ocenie zgodności krajowych regulacji prawa pracy ze standardami ochrony trwałości stosunku pracy wynikającymi z art. 24 Zrewidowanej Europejskiej Karty Społecznej (ZEKS). Asumptem do podjęcia niniejszych rozważań jest kwestia ratyfikacji ZEKS przez Polskę, która powróciła do dyskursu publicznego po raz kolejny od momentu jej podpisania w dniu 25 października 2005 r. Przyjęcie ZEKS związane było z dążeniem do aktualizacji i dostosowania Europejskiej Karty Społecznej do zmian w dziedzinie stosunków społecznych i gospodarczych. Jednym z „nowych” praw uznanych w ZEKS jest prawo pracowników do ochrony przed nieuzasadnionym zwolnieniem z pracy, które wraz z pozostałymi prawami zawartymi w Karcie zalicza się do podstawowych praw socjalnych.

Słowa kluczowe: Europejska Karta Społeczna, Zrewidowana Europejska Karta Społeczna, ochrona przed rozwiązaniem stosunku pracy

\section{TOWARDS THE RATIFICATION OF THE REVISED EUROPEAN SOCIAL CHARTER - POLAND VS THE STANDARDS OF THE REVISED CHARTER REGARDING THE PROTECTION OF EMPLOYMENT RELATIONSHIP}

\section{Su m m a ry}

This article concentrates on the evaluation of compliance of the Polish national labor law regulations with the standards of protection of the durability of employment relationship arising out of Article 24 of the Revised European Social Charter. This discussion was inspired by the issue of ratification of the Revised Charter by Poland that returned to the public discourse once again after its 
signature on 25 October, 2005. The adoption of the Revised Charter was connected with the pursuit of updating the Charter and adapting it to the changes occurring in the social and economic relationships. One of the "new" rights recognized in the Revised Charter is workers' right to protection from dismissal without a valid reason, which - like the other rights provided for in the Charter - is regarded as a fundamental social right.

Key words: European Social Charter, Revised European Social Charter, protection against unjustified termination of employment

\section{НА ПУТИ К РАТИФИКАЦИИ ПЕРЕСМОТРЕННОЙ ЕВРОПЕЙСКОЙ СОЦИАЛЬНОЙ ХАРТИИ - ПОЛЬША ПО ОТНОШЕНИЮ К СТАНДАРТАМ ПЕСХ ОТНОСИТЕЛЬНО ЗАЩИТЫ ДОЛГОВРЕМЕННЫХ ТРУДОВЫХ ОТНОШЕНИЙ}

\section{Резюме}

В настоящей статье основное внимание уделяется оценке соответствия национальных норм трудового законодательства стандартам защиты продолжительности трудовых отношений в соответствии со ст. 24 Пересмотренной Европейской социальной хартии (ПЕСХ). Причиной для проведения этого исследования является вопрос о ратификации ПЕСХ Польшей, который вновь вернулась в публичный дискурс после ее подписания 25 октября 2005 года. Принятие ПЕСХ было связано с желанием обновить и адаптировать Европейскую социальную хартию к изменениям в области социальных и экономический отношений. Одним из «новых» прав, признанных в ПЕСХ является право работников на защиту от необоснованного увольнения, которое наряду с другими правами, содержащимися в Хартии, включено в разряд основных социальных прав.

Ключевые слова: Европейская социальная хартия, Пересмотренная Европейская социальная хартия, защита от прекращения трудовых отношений 
